\title{
Perception on Occurrence of Medication Errors and Its Prevention among Nursing Officers
}

\author{
Solomon James Mangalaraj ${ }^{1}$, Binu Mathew ${ }^{2}$, Anjali Pandey ${ }^{3}$, \\ Anjali Kumari Jaiswal ${ }^{4}$, Anmol ${ }^{5}$, Archana A J ${ }^{6}$, Arti Kumari ${ }^{7}$, Dayna ${ }^{8}$ \\ ${ }^{1} \mathrm{PhD}$ Nursing, Faculty, College of Nursing, AIIMS RAIPUR \\ ${ }^{2}$ Assistant Professor, College of Nursing, AIIMS RAIPUR \\ ${ }^{3-8}$ B.Sc. (Hons.) Nursing, College of Nursing, AIIMS RAIPUR \\ Corresponding Author: Solomon James Mangalaraj
}

\begin{abstract}
Aim of the study was to assess the perception on occurrence of medication error and to assess the perception on prevention of medication error among nursing officers in wards at a selected hospital, Raipur.

\section{Objectives}

- To assess the perception on occurrence of medication error among nurses.

- To assess the perception on prevention of medication error among nurses.

Review of literature was prepared relevant to the study. The conceptual framework of the study was based on” Imogene King's Goal Attainment Theory”. Pilot study was done among nurses in selected wards at a selected hospital, Raipur. The main study was conducted in selected wards at a selected hospital, Raipur. A total of 60 nursing officers were included in the study and they were selected using non probability convenience sampling technique. The instrument used for data collection was standard 5-point Likert rating scale. Validity and reliability of the tool were done. Data were collected for the period of 4 weeks. Descriptive statistics was used to analyze the data. It was observed in the present study that majority (74\%) of the total sample of nursing officers had adequate perception on occurrence of medication error and (82\%) of the total sample of nurses had adequate perception on prevention of medication error.
\end{abstract}

Keywords: Medication errors, Perception, Occurrence, Prevention, Nursing officers

\section{INTRODUCTION}

Patient safety is a global health priority. According to WHO safety of patient during the provision of health service that are safe and of high quality are prerequisite for strengthening health care system and making progress towards effective universal health coverage. Every year millions of patients suffer from injuries or die because of unsafe and poor-quality health care. Many health practices and risks associated with health care are emerging as major challenge for patient safety and contribute significantly to the burden of harm due to unsafe care. Medication error is one risk that is causing most concern. Medication error are a leading cause of injury and avoidable harm in health care system; globally the cause associated with medication error has been estimated to US\$ 42 billion.

Many studies have described medication error rates in hospital settings, but the data for primary care is relatively scarce. This is particularly true of low- and middle-income countries, despites the increasing use of medicine. It is considering being one of the most common causes of morbidity and mortality cases occurring in hospital settings [1], and also a major health 
care provider issue affecting the quality and continuity of the health care services [2].

There has been reported evidence of medication error in the developed world. Studies on medication administration errors rates and safety mostly carried out in the developed countries has varying reported incidences of $3.3 \%, 10 \%, 19.5 \%$, and $22.2 \%$, while studies carried out in developing countries have found very high medication administration rates of $56.4 \%$ and $94 \%$ [3]. The proportion of medication error among nurses vary in different study, it was $57.4 \%$ in Ethiopia $42.1 \%$ in Jordan, 41.9\% in Australia and $28.9 \%$ in USA [4]. Annually 7000 mortalities have been reported due to medication errors. As per study $48.39 \%$ of medication error cases out of 100 prescriptions were reported in India.[5]

In India, medication error and medical related problem mainly occur due to irrational use of medication. Error happens due to lack of knowledge, poor performance and psychological lapses. A number of studies have examined factors associated with the medication error like lack of therapeutic training, inadequate knowledge and experience, inadequate knowledge of the patient, inadequate perceptions of the risk, overworked or fatigued healthcare professionals, physical and emotional health issues, and poor communication between healthcare professional and with patients.

Many nursing officers are not aware of how to prevent medication error. Educating nursing officers about prevention of medication error is a comprehensive measure [3]. Nursing officers as direct provider of care have an important function when it comes to patient safety. Hence, their important role cannot be overemphasized in medication administration as it is a vital core work of nursing officers on daily basis. It is therefore necessary to find out their perception on occurrence of medication error and its prevention to institute safer practice in hospitals for quality patient care.

\section{Statement of problem}

A descriptive study to assess the perception on occurrence of medication errors and its prevention among the nursing officers in wards at a selected hospital, Raipur.

\section{Objectives of the study}

1. To assess the perception on occurrence of medication error among nursing officers.

2. To assess the perception on prevention of medication error among nursing officers.

\section{Operational definition}

\section{- Medication error}

Medication error is any preventable event that may cause or lead to inappropriate medication use or patient harm such as omission of drug, wrong dose, extra dose, unordered drug, wrong rate and wrong time.

\section{- Prevention}

It refers to measures which are undertaken by nursing officers to control the occurrence of medication error.

\section{- Occurrence}

It refers to an unusual event which adversely affects or threatens the health or life of the patients.

\section{- Perception}

Perception is defined as ability to understand about the occurrence and prevention of medication errors.

\section{RESEARCH METHODOLOGY RESEARCH APPROACH}

A quantitative research approach was for the study as the study aims at assessing the perception on occurrence of medication error and its prevention among nurses.

\section{RESEARCH DESIGN}

A descriptive research design was selected for the study. 


\section{SETTING OF THE STUDY}

The study was conducted in selected wards at a selected hospital, Raipur. The main study conducted in General Medicine and Surgery wards of a selected hospital, Raipur.

\section{POPULATION}

Nursing officers working at a selected hospital, Raipur.

\section{SAMPLE AND SAMPLE SIZE}

The sample of the study consists of 60 nursing officers working in a selected hospital, Raipur.

\section{SAMPLING TECHNIQUE}

Non probability convenience sampling technique was used.

\section{DATA COLLECTION TECHNIQUE}

Standard 5 Point Likert rating scale questionnaire through online response.

\section{DESCRIPTION OF DATA COLLECTION INSTRUMENT}

The tool consists of two sections:

1. DEMOGRAPIC PROFORMA: It is a self-structured questionnaire formed to collect selected demographic variables including: age, gender, educational qualification, marital status, hospital experience and employee status.

2. SELF STRUCTURED QUESTIONNAIRE: It is a selfstructured questionnaire made to suit the study design and study objectives. The questionnaire is divided into two sections.

Section 1 - It includes questions to assess the perception on occurrence of medication error among nursing officers. It consists of 14 Likert scale question that had five-point scale to measure the perception of nursing officers on occurrence of medication error. Section 2 - It includes questions to collect data related to perception on prevention of medication error. It consists of 14 questions Likert scale question that had five-point scale to measure the perception of nursing officers on prevention of medication error.

\section{SCORING}

The Likert scale question had fivepoint scale to measure the perception of nursing officers on prevention of medication error. The scoring of Likert scale is done on the basis of the type of question and level of respondent's agreement by statement. In case of positive statement, respondent get higher score if there is agreement with the statement.

For the Likert scale used in study, the score provided are as following:

STRONGLY AGREE- 5

$\begin{array}{ll}\text { AGREE - } & 4 \\ \text { UNCERTAIN - } & 3 \\ \text { DISAGREE - } & 2\end{array}$

STRONGLY DISAGREE- 1

The total attainable score in 5-point Likert rating scale was 70 . The total score will be converting into following ranges.

\section{LEVEL OF PERCEPTION SCORE (\%) \\ Inadequate - $\quad \leq 50 \%$ \\ Moderately adequate - $51-75 \%$ \\ Adequate - $\quad>75-100 \%$}

\section{VALIDITY}

Content validity of tool was obtained from 5 experts in Pharmacology and Nursing departments. The experts were requested to give their opinions and suggestions.

\section{PRETESTING AND RELIABILITY}

The reliability of the tool was obtained by administering it to $10 \%$ of the sample. The stability of the Likert scale on the perception of occurrence on medical error and its prevention was done by Spearman's Rank Correlation Coefficient method. In order to establish reliability, the tool was administered to 6 nursing officers who satisfied sampling criteria. The reliability quotient obtained for the tool was 0.99 . Hence, the tool was found reliable. 


\section{PILOT STUDY}

Pilot study was conducted through online method. One tenth of the sample was selected who fulfilled the inclusive criteria by using non probability convenience sampling technique; informed written consent was taken from samples.

\section{PROCEDURE FOR DATA COLLECTION}

A formal permission was obtained from the concerned authority. The study was conducted among 60 samples by using non probability convenience sampling technique based on inclusion and exclusion criteria. Firstly, a brief introduction of self, consent of the sample and the confidentiality of the responses were assured. The data were collected by the standard 5 point Likert scale to assess the perception of occurrence of medication errors and its prevention among nursing officers.

\section{ANALYSIS AND DISCUSSION \\ SECTION 1}

Perception on occurrence of medication errors among nursing officers.

\begin{tabular}{|c|c|c|c|c|c|c|}
\hline QUESTIONS & TOTAL & $\begin{array}{l}\text { STRONGLY } \\
\text { AGREE (\%) } \\
\end{array}$ & $\begin{array}{l}\text { AGREE } \\
(\%)\end{array}$ & $\begin{array}{l}\text { UNCERTAIN } \\
(\%)\end{array}$ & $\begin{array}{l}\text { DISAGREE } \\
(\%)\end{array}$ & $\begin{array}{l}\text { STRONGLY } \\
\text { DISAGREE (\%) }\end{array}$ \\
\hline $\begin{array}{l}\text { 1. Verbal order } \\
\text { during emergency. }\end{array}$ & 60 & 21.67 & 61.67 & 11.67 & 3.33 & 1.67 \\
\hline $\begin{array}{l}\text { 2. Staff not } \\
\text { having } \\
\text { adequate } \\
\text { experience. }\end{array}$ & 60 & 20 & 40 & 18.33 & 20 & 1.67 \\
\hline $\begin{array}{l}\text { 3. Complex } \\
\text { medication } \\
\text { dosage } \\
\text { calculation. }\end{array}$ & 60 & 10 & 56.67 & 21.67 & 11.67 & 0 \\
\hline $\begin{array}{l}\text { 4. Tiredness } \\
\text { resulting from } \\
\text { overworking. }\end{array}$ & 60 & 20 & 60 & 13.33 & 5 & 1.67 \\
\hline $\begin{array}{l}\text { 5. Use of } \\
\text { abbreviations. }\end{array}$ & 60 & 25 & 48.33 & 13.33 & 11.67 & 1.67 \\
\hline $\begin{array}{l}\text { 6. Due to look alike } \\
\text { and soundalike drugs. }\end{array}$ & 60 & 26.67 & 45 & 15 & 13.33 & 0 \\
\hline $\begin{array}{l}\text { 7. Decreasing patient } \\
\text { to nurse staffing ratio. }\end{array}$ & 60 & 23.33 & 56.67 & 11.67 & 8.33 & 0 \\
\hline $\begin{array}{l}\text { 8. Unfamiliaritywith } \\
\text { drugs. }\end{array}$ & 60 & 16.67 & 45 & 20 & 18.33 & 0 \\
\hline $\begin{array}{l}\text { 9. Not having } \\
\text { psychological and } \\
\text { mental wellbeing }\end{array}$ & 60 & 20 & 43.33 & 15 & 21.67 & 0 \\
\hline $\begin{array}{l}\text { 10. Different } \\
\text { physician giving } \\
\text { different medication } \\
\text { order for same } \\
\text { patient. }\end{array}$ & 60 & 23.33 & 48.33 & 11.67 & 16.67 & 0 \\
\hline $\begin{array}{l}\text { 11. Lack of } \\
\text { pharmacological } \\
\text { training session for } \\
\text { updating knowledge } \\
\text { and skills. }\end{array}$ & 60 & 18.33 & 46.67 & 20 & 15 & 0 \\
\hline $\begin{array}{l}\text { 12. Not interested } \\
\text { in different } \\
\text { additional } \\
\text { pharmacology } \\
\text { courses. }\end{array}$ & 60 & 15.00 & 31.67 & 21.67 & 31.67 & 0 \\
\hline $\begin{array}{l}\text { 13. Not following } \\
\text { properly rights of } \\
\text { medication } \\
\text { administrations. } \\
\end{array}$ & 60 & 21.67 & 40 & 18 & 20 & 0 \\
\hline $\begin{array}{l}\text { 14. Poor } \\
\text { communication } \\
\text { with doctors. }\end{array}$ & 60 & 13.33 & 60 & 15 & 11.67 & 0 \\
\hline
\end{tabular}




\section{RESULTS OF TABLE 1}

Table 1 highlights the nurse officer's perception on occurrence of medication error. The results of the study can be analyzed as follows. $61.67 \%$ of the nursing officers agreed that verbal orders during emergency can lead to medication errors.40\% of the nursing officers acknowledged that staff not having adequate experience can contribute to medication error. $56.67 \%$ of the nursing officers granted that complex medication dosage calculation account for medication error.60\% of the nursing officers admitted that tiredness resulting from overwork are identifiable causes of medication errors.45\% nursing officers concurred that look alike and sound alike and unfamiliarity with drugs can lead to medication error.31.67\% of the nursing officers were interested in different additional pharmacological courses.56.67\% nursing officers recognized that decreasing patient nurse ratio can reduce medication error.48.33\% nursing officers conceded that different physician giving different medication order for same patient and use of abbreviations are accountable for medication error. $40 \%$ of the nursing officers acknowledged that non- adherence to rights of medication administration results in medication error. $60 \%$ of the nursing officers identified that poor communication with doctors is an identifiable cause of medication error.

Table 2: Level of perception on occurrence of medication error among nursing officers.

\begin{tabular}{|l|c|c|}
\hline LEVEL OF PERCEPTION & Frequency & Percentage (\%) \\
\hline INADEQUATE & 1 & 1.66 \\
\hline MODERATELY ADEQUATE & 30 & 50 \\
\hline ADEQUATE & 29 & 48.33 \\
\hline
\end{tabular}

Table 2 highlights level of perception among nursing officers. The result of the study can be analysed as follows, $1.66 \%$ of nursing officers had inadequate level of perception regarding occurrence of medication errors, $50 \%$ of nursing officers had moderately adequate level of perception regarding occurrence of medication errors and $48.33 \%$ of nursing officers had adequate level of perception regarding occurrence of medication errors.

\section{Level of perception on occurrence of medication error among nursing officers}

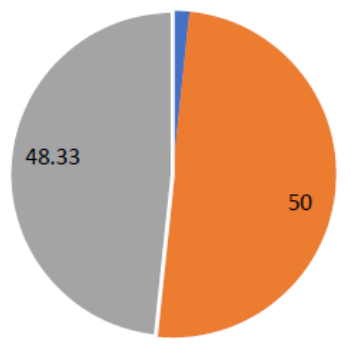

- Inadequate perception

Moderately adequate perception

Adequate perception

Fig. 1: Graphical representation of level of perception of medication error among nursing officers.

SECTION - 2

Perception on prevention of medication error among nursing officers.

Table 3: Perception on prevention of medication error.

\begin{tabular}{|l|c|c|c|c|c|c|}
\hline QUESTION & TOTAL & $\begin{array}{c}\text { STRONGLY } \\
\text { AGREE\% }\end{array}$ & AGREE \% & UNCERTAIN\% & DISAGREE\% & $\begin{array}{l}\text { STRONGLY } \\
\text { DISAGREE\% }\end{array}$ \\
\hline $\begin{array}{l}\text { 1. Discontinuation of the } \\
\text { use of handwrittenorders. }\end{array}$ & 60 & 23.33 & 31.67 & 21.67 & 16.67 \\
\hline $\begin{array}{l}\text { 2. Cessation ofuse of } \\
\text { abbreviations. }\end{array}$ & 60 & 11.67 & 55 & 20 & 10 \\
\hline $\begin{array}{l}\text { 3. Creating conducive } \\
\text { workenvironment. }\end{array}$ & 60 & 25 & 56.67 & 13.33 & 3.33 \\
\hline
\end{tabular}


Solomon James Mangalaraj et.al. Perception on occurrence of medication errors and its prevention among nursing officers.

\begin{tabular}{|c|c|c|c|c|c|c|}
\hline \multicolumn{7}{|c|}{ Table 3 Continued... } \\
\hline $\begin{array}{l}\text { 4. Followingrights } \\
\text { of medication } \\
\text { administration. }\end{array}$ & 60 & 46.67 & 41.67 & 5 & 5 & 1.67 \\
\hline $\begin{array}{l}\text { 5. Following three } \\
\text { checks ofmedication } \\
\text { administration. }\end{array}$ & 60 & 50 & 35 & 10 & 3.33 & 1.67 \\
\hline $\begin{array}{l}\text { 6. Bar coded medication } \\
\text { administration. }\end{array}$ & 60 & 21.67 & 46.67 & 25 & 3.33 & 3.33 \\
\hline $\begin{array}{l}\text { 7. Proper } \\
\text { documentationof } \\
\text { medication } \\
\text { administration. }\end{array}$ & 60 & 50 & 43.33 & 1.67 & 3.33 & 1.67 \\
\hline $\begin{array}{l}\text { 8. Avoid usingverbal } \\
\text { orders as routine } \\
\text { practice. }\end{array}$ & 60 & 45 & 45 & 6.67 & 3.33 & 0 \\
\hline $\begin{array}{l}\text { 9. Effective } \\
\text { communication between } \\
\text { medication provider and } \\
\text { patient. }\end{array}$ & 60 & 40 & 51.67 & 1.67 & 3.33 & 3.33 \\
\hline $\begin{array}{l}\text { 10. Store medications } \\
\text { with look- alikenames } \\
\text { in different locations. }\end{array}$ & 60 & 43.34 & 43.33 & 5 & 5 & 3.33 \\
\hline $\begin{array}{l}\text { 11. Using different } \\
\text { color label containerto } \\
\text { store different strength } \\
\text { of same medications. }\end{array}$ & 60 & 36.67 & 50 & 10 & 1.67 & 1.67 \\
\hline $\begin{array}{l}\text { 12. Minimize using } \\
\text { brand names of drugs } \\
\text { to avoid } \\
\text { confusion. }\end{array}$ & 60 & 43.34 & 46.67 & 5 & 3.33 & 1.66 \\
\hline $\begin{array}{l}\text { 13. Providing } \\
\text { continuing education } \\
\text { onmedication } \\
\text { storage and } \\
\text { administration. }\end{array}$ & 60 & 43.34 & 46.67 & 3.33 & 3.33 & 3.33 \\
\hline $\begin{array}{l}\text { 14. Reporting } \\
\text { medication error }\end{array}$ & 60 & 46.67 & 45 & 3.33 & 3.33 & 1.67 \\
\hline
\end{tabular}

\section{RESULTS OF TABLE 3}

Table 3 highlights the nursing officer's perception on prevention of medication error.

$56.67 \%$ of the nursing officers concurred that working in conducive environment will result in decrease in medication error.55\% of the nursing officers agreed that cessation of use of abbreviations contribute to reduction in medication error. $51.67 \%$ of the nursing officers conceded that effective communication between the medication provider and patient can decrease the incidence of medication error. $50 \%$ of the nursing officers acknowledged that ensuring 3 checks of medication administration and proper documentation can prevent medication errors.46.67\% nursing officers agree that reporting medication error, bar-coded medication administration, following rights of medication error, minimize using brand names of drugs and providing continuing education can decline the number of medication error cases.45\% of the nursing officers acknowledged that avoid using verbal orders as a routine practice can lessen the incidence of medication error. $43.34 \%$ nursing officers strongly agreed that storing look-alike medications in different locations can decline the cases of medication error. $36.67 \%$ of the nursing officers recognized that using different color label container to store different strength of the same medication more likely to lessen the incidence of medication error.31.67\% of the nursing officers acknowledged that discontinuation of use of handwritten orders will be accountable for fall- off in the incidence of medication error.

Table 4: Level of perception regarding prevention of medication errors among nursing officers.

\begin{tabular}{|l|c|c|}
\hline $\begin{array}{l}\text { LEVEL OF } \\
\text { PERCEPTION }\end{array}$ & Frequency & $\begin{array}{c}\text { Percentage } \\
\text { (\%) }\end{array}$ \\
\hline INADEQUATE & 2 & 3.33 \\
\hline $\begin{array}{l}\text { MODERATELY } \\
\text { ADEQUATE }\end{array}$ & 8 & 13.33 \\
\hline ADEQUATE & 50 & 83.33 \\
\hline
\end{tabular}



nursing officers.

Table 4 highlights the level of perception on prevention of medication error among nursing officers. 3.33\% of nursing officers had inadequate level of perception regarding medication errors.
$13.33 \%$ of nursing officers had moderately adequate level of perception regarding medication errors.83.33\% of nursing officers had adequate level of perception regarding medication errors.

\section{Level of perception of occurrence of medication error among nursing officer}

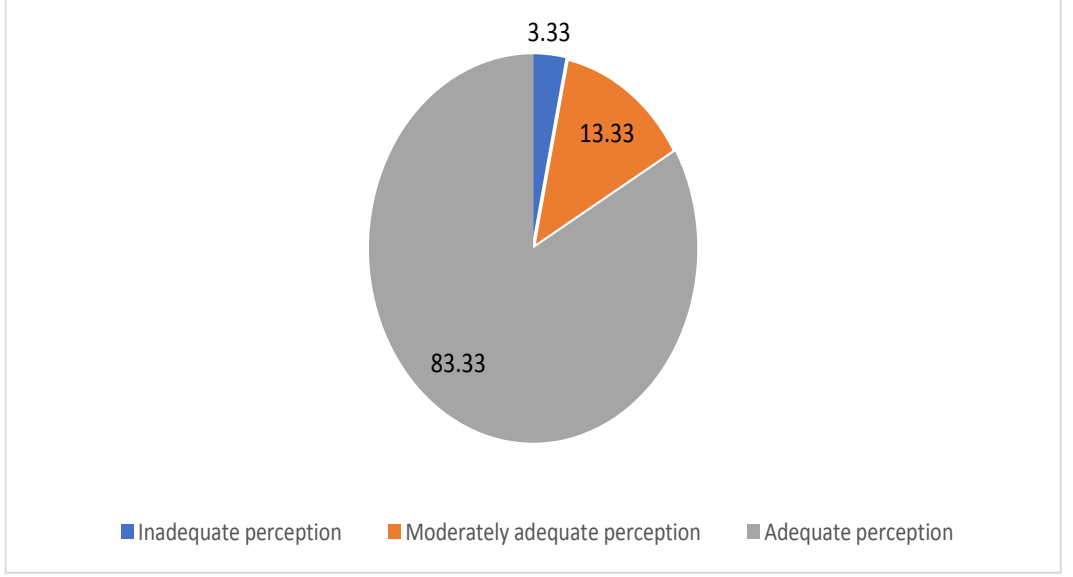

Fig. 2: Level of perception on prevention of medication error among nursing officers.

\section{CONCLUSION}

The focus of the present study was to assess the perception on occurrence of medication error and its prevention among nursing officers at selected wards of AIIMS Raipur. Quantitative research approach and descriptive research design was used for the study, conceptual framework of the study was based upon "Imogene King's Goal Attainment Theory”. The instrument used for data collection was standard 5-point Likert rating scale which was prepared on the basis of review of literature and with the help of the subject experts. Reliability of the tool was elicited by using Spearman's rank correlation coefficient.

A total of 60 samples who met the inclusion criteria were selected by the simple non probability convenience sampling technique. Written consent was obtained from the samples. Data were collected over a period of 4 weeks. Data collection was planned and gathered using standard 5-point Likert rating scale. The main study was conducted at selected General medicine and surgery wards of a selected hospital, Raipur. Descriptive and inferential statistics were used for analysis and data were presented using table and graph.

The study result shows that it was observed that $48.33 \%$ of nursing officers had adequate level of perception regarding occurrence of medication errors and $83.33 \%$ of nursing officers had adequate level of perception regarding prevention of medication errors. Nursing officers agreed that verbal order, less work experience, complex medication dose calculation, tiredness, prescription of look-alike and sound alike drug, increased nurse patient ratio, lack of communication with doctors, not following all rights of medication were the causes of medication errors.

Nursing officers also agreed that conducive work environment, improved communication between doctor, nurse and patient, ensuring three checks and proper documentation, reporting medication error, medication administration, following rights of medication error, minimize using brand names of drugs and providing continuing education can decline the number of medication error cases. 


\section{IMPLICATIONS}

\section{NURSING PRACTICE}

The nursing officers would benefit from this study since their perception on occurrence and prevention of medication errors would be known and their concerns would be addressed. The results of the study would also help in formulating new guidelines to prevent medication errors and improve patient safety. Patient safety work culture can be developed improving staff communication and health safety of health workers also helps to prevent and reduce risks.

\section{NURSING EDUCATION}

The study findings can be utilized to plan and conduct continuing nursing education programmes for nursing officer's and plan curriculum for nursing students to prevent medication errors and constantly updating the latest knowledge and skill.

\section{NURSING ADMINISTRATION}

The nursing administrators will benefit from this study. Through the results of this study, they will be informed as to how the nursing officers perceive medication errors. Based on the findings, they can revise their present policies or formulate new ones regarding medication errors and its prevention.

\section{NURSING RESEARCH}

Our study, being a descriptive one, raises a number of opportunities for future research, both in terms of theory development and content validation. This study will serve as a reference and guide for future researchers, who will be conducting a study on medication errors. Investments in reducing harm can lead to significant financial savings and better patient outcomes.

\section{LIMITATIONS}

- The study was confined to only nursing officers working in selected wards of a selected hospital, Raipur.
- The study adopted convenient sampling technique; hence the generalization of the findings outside the sample size is limited.

- A structured questionnaire was used for data collection, which restrict the amount of information that could be obtained from the respondents.

\section{RECOMMENDATIONS}

- A study to assess the different practices used for prevention of medication errors can be conducted.

- A comparative study may be conducted to assess the medication errors encountered by physician and nursing officers.

- A study can be done to find new solutions to prevent medication errors.

- A retrospective study can be done on consequences of medication errors.

\section{Acknowledgement: None}

\section{Conflict of Interest: None}

\section{Source of Funding: None}

Ethical Approval: Approved

\section{REFERENCES}

1. WHO Medication Errors Dashboard [Internet]Medication Error.who.int.2016 [cited 2016]. Available from: https://apps.who.int/iris/bitstream/handle/10 665/252274/9789241511643-

eng.pdf;sequence $=1$

2. Bothiraj M, Alagusundaran M, Sekhar KBC. A study on prevalence of medication errors in a multispecialty hospital. Int. J. Pharm. Sci. Res. [Internet].2020[cited 2020 Jan 03]:2444-47 Available From : https://ijpsr.com/bft-article/a-study-onprevalence-ofmedication-errors-in-a-multispecialityhospital/?view=fulltext DOI:10.13040/IJPSR.09758232.11(5).2444-47

3. Ayorinde MO, Alabi PI. Perception and contributing factors to medication administration errors among nursing officers 
Solomon James Mangalaraj et.al. Perception on occurrence of medication errors and its prevention among nursing officers.

in Nigeria. Int. J. Africa Nurs. Sci.[Internet].2019;11:Available From : https://www.sciencedirect.com/science/artic le/pii/S2214139118301604

4. Jember A, Gebrie M, Messele A, Demeke T, Hassen M. Proportion of medication error reporting and associated factors among nursing officers: A cross sectional study. BMC Nurs.[Internet].2018[cited 2018 March 12];17(9)

Available

from:

https://www.researchgate.net/publication/32 3717806_Proportion_of

_medication_error_reporting_and_associate d_factors_among_nursing

officers_A_cross_sectional_study

5. Sheikh D, Mateti UV, Kabekkodu S, Sanal $\mathrm{T}$. Assessment of medication errors and adherence to WHO prescription writing guidelines in a tertiary care hospital. Future J Pharm Sci.[Internet].2017.[cited 2017];3(1):60-64 Available From: https://www.sciencedirect.com/science/artic le/pii/S2314724516300401

6. Pavithra K, Latha S, Joseph G, Sujatha.R, Rao J. Perception of Medication error among Interns and Staff Nursing officers in a Selected Hospital at Mangalore- A Mixed Method Approach. Med. Legal Update[Internet]2016 [cited 2020 JulySeptember];20:(3):1- 7

Available

From: http://ijop.net/index.php/mlu/article/downlo ad/1413/1287/2632

7. Petrova E, Baldacchino DR, Camilleri M. Nurse's perceptions of medication errors in Malta. Nursing standard: official newspaper of the Royal College of Nursing [Internet].2010 [cited 2010 April];24:(33):41-48 Available From: https://www.researchgate.net/publication/27 2692231_Nursing

officers'_perceptions_of_medication_errors _in_MaltaDOI

$: 10.7748 / \mathrm{ns} 2010.04 .24 .33 .41 . c 7717$

8. Mayo AM, Denise D. Nurse Perceptions of Medication Errors: What We Need to Know for Patient Safety. J. Nurs. Care Qual.[Internet].2004 [cited 2004 JulySeptember];19:(3):209 -17 Available From: https://www.nursingcenter.com/journalarticl e?Article_ID=514523\&Journal ID $=54010 \&$ Issue_ID $=514497$

9. Bohomol E, Ramos LH.Perceptions about medication errors: Analysis of answers by the nursing team.Rev. Latino-Americana de Enfermagem [Internet].2006 [cited 2006 Dec];14(6):887-92.Available From: https://www.researchgate.net/publication/65 11264_Perceptions_about_me dication_errors_Analysis_of_answers_by_th e_nursing_team DOI:10.1590/S010411692006000600009

10. Gehan Abd Elfattah Elasrag, Hana Mohammad Abu-Snieneh. Nurses' Perception of Factors Contributing to Medication Administration Errors. ijrps [Internet]. 2020Jan.4 [cited 2021Nov.16];11(1):44-6. Available from: https://pharmascope.org/index.php/ijrps/arti cle/view/1781 https://doi.org/10.26452/ijrps.v11i1.1781

11. Ramya K.R, Vineetha R. Nursing officers' Perceptions of Medication Errors in South India. Asian J. Nurs. Edu. Res.[Internet].2014[cited 2014 JanMarch];4(1):20-25.Available

From:https://ajner.com/AbstractView.aspx? $\mathrm{PID}=2014-4-1-5$

12. Samsiah A, Othman N, Jamshed S, Hassali MA. Perception and attitude towards medication error reporting in primary care clinics: A qualitative study in Malaysia.PLOS. One.2016[cited 2016 Dec 01];10(2):1-2 Available From:https://journals.plos.org/plosone/articl e?id=10.1371/journal.pone.0166114 DOI:10.1371/journal.pone.0166114

13. Tariq RA, Vashisht R, Sinha A, et al.Medication Dispensing Errors And Prevention.2021[cited 2021 Jan]Available From:https://www.ncbi.nlm.nih.gov/books/ NBK519065/

14. Kim KS,Kwon SH, Kim JA, Cho S.Nursing officers perception of medication errors and their contributing factors in South Korea J Nurs Manag.[Internet].2011[cited 2011April];19(3):346-53 Available From:https://pubmed.ncbi.nlm.nih.gov/2150 7105/DOI:10.1111/j.13652834.2011.01249.x.

15. Ambwani S, Misra AK, Kumar R. Medication Errors: Is it the hidden part of the submerged iceberg in our health care system? Int J App Basic Med Res[Internet]2019[cited 2019 JulySept];9(3):135-42Available From:https://pubmed.ncbi.nlm.nih.gov/3139 2175/DOI 10.4103/ijabmr.IJABMR_96_19. 

nursing officers.

16. Salar A, Kiani F, Rezaee N. Preventing the medication errors in hospitals : A qualitative study[Internet]2020 [cited 2020 August 10];13(3)Available

From:https://www.sciencedirect.com/scienc e/article/pii/S2214139120301128

17. Samundeeswari A, Muthamilselvi G.Nursing officers knowledge on prevention of medication error[Internet]2018[cited 2018 March];6(3) /http://jmscr.igmpublication.org/DOI: https://dx.doi.org/10.18535/jmscr/v6i3.45

18. Athanasakis E. Prevention of medication errors made by nursing officers in clinical practice. Health Sci. J.[Internet]2012 [cited 2021
83.AvailablFrom:https://www.researchgate. net/publication/268140790_Prevention_of_ medication_errors_made_by_nursing officers_in_clinical_practice

19. Sharma S K. Nursing Research and Statistics.3rd Edition, New Delhi: Elsevier Publishers Limited 2019:10-200.

How to cite this article: Mangalaraj SJ, Mathew B, Pandey A et.al. Perception on occurrence of medication errors and its prevention among nursing officers. Int J Health Sci Res. 2021; 11(11): 286-295. DOI: https://doi.org/10.52403 /ijhsr.20211134 